Sustainability Science • Sustainability Science: A guide for researchers

\title{
Literature Cited in the Research Guide
}

\author{
Alicia G. Harley, William C. Clark
}

Published on: Oct 05, 2020

DOI: $10.21428 / \mathrm{f} 8 \mathrm{~d} 85 \mathrm{a} 02.9765 \mathrm{c} 8 \mathrm{c} 7$

License: Creative Commons Attribution 4.0 International License (CC-BY 4.0). 
Cite as: Harley, Alicia G., and William C. Clark. 2020. "Literature Cited in the Research Guide." In Sustainability Science: A Guide for Researchers, edited by Alicia G. Harley and William C. Clark, 1st ed. Retrieved from https://www.sustainabilityscience.org/pub/3gljq9su

Abbott, Kenneth W., and Steven Bernstein. 2015. "The High-Level Political Forum on Sustainable Development: Orchestration by Default and Design." Global Policy 6 (3): 222-33.

https://doi.org/10.1111/1758-5899.12199.

Adger, W. Neil. 2006. "Vulnerability." Global Environmental Change, Resilience, Vulnerability, and Adaptation: A Cross-Cutting Theme of the International Human Dimensions Programme on Global Environmental Change, 16 (3): 268-81. https://doi.org/10.1016/j.gloenvcha.2006.02.006.

- 2016. "Place, Well-Being, and Fairness Shape Priorities for Adaptation to Climate Change." Global Environmental Change 38 (May): Al-3. https://doi.org/10.1016/j.gloenvcha.2016.03.009.

Adger, W. Neil, and Andrew Jordan, eds. 2009. Governing Sustainability. Cambridge; New York: Cambridge University Press.

Agarwal, Priti, and Aparna Sawhney. 2020. "Sustainability and Comprehensive Wealth Accounting: The Case of India." Environment, Development and Sustainability, April. https://doi.org/10.1007/s10668020-00743-9.

Agrawal, Arun. 2003. "Sustainable Governance of Common-Pool Resources: Context, Methods, and Politics." Annual Review of Anthropology 32 (1): 243-62.

https://doi.org/10.1146/annurev.anthro.32.061002.093112.

- 2014. "Studying the Commons, Governing Common-Pool Resource Outcomes: Some Concluding Thoughts." Environmental Science \& Policy, Interrogating The Commons, 36: 86-91. https://doi.org/10.1016/j.envsci.2013.08.012.

Agyeman, Julian, David Schlosberg, Luke Craven, and Caitlin Matthews. 2016. “Trends and Directions in Environmental Justice: From Inequity to Everyday Life, Community, and Just Sustainabilities." Annual Review of Environment and Resources 41 (1): 321-40. https://doi.org/10.1146/annurev-environ110615-090052.

Ahlborg, Helene, Ilse Ruiz-Mercado, Sverker Molander, and Omar Masera. 2019. “Bringing Technology into Social-Ecological Systems Research-Motivations for a Socio-Technical-Ecological Systems Approach." Sustainability 11 (7): 2009. https://doi.org/10.3390/sul1072009. 
Ahlquist, John S. 2017. "Labor Unions, Political Representation, and Economic Inequality." Annual Review of Political Science 20 (1): 409-32. https://doi.org/10.1146/annurev-polisci-051215-023225.

Amenta, Edwin, and Francesca Polletta. 2019. “The Cultural Impacts of Social Movements." Annual Review of Sociology 45 (1): 279-99. https://doi.org/10.1146/annurev-soc-073018-022342.

Anadon, Laura Diaz, Gabriel Chan, Alicia G. Harley, Kira Matus, Suerie Moon, Sharmila L. Murthy, and William C. Clark. 2016. "Making Technological Innovation Work for Sustainable Development." Proceedings of the National Academy of Sciences 113 (35): 9682-90. https://doi.org/10.1073/pnas.1525004113.

Anderies, John, Carl Folke, Brian Walker, and Elinor Ostrom. 2013. "Aligning Key Concepts for Global Change Policy: Robustness, Resilience, and Sustainability." Ecology and Society 18 (2): art8. https://doi.org/10.5751/ES-05178-180208.

Anderies, John M. 2015. "Managing Variance: Key Policy Challenges for the Anthropocene." Proceedings of the National Academy of Sciences 112 (47): 14402-3. https://doi.org/10.1073/pnas.1519071112.

Anderies, John M., Jean-Denis Mathias, and Marco A. Janssen. 2019. "Knowledge Infrastructure and Safe Operating Spaces in Social-Ecological Systems." Proceedings of the National Academy of Sciences 116 (12): 5277-84. https://doi.org/10.1073/pnas.1802885115.

Andonova, Liliana B. 2017. Governance Entrepreneurs: International Organizations and the Rise of Global Public-Private Partnerships. Business and Public Policy. Cambridge; New York: Cambridge University Press.

Apajalahti, Eeva-Lotta, Armi Temmes, and Tea Lempiälä. 2018. "Incumbent Organisations Shaping Emerging Technological Fields: Cases of Solar Photovoltaic and Electric Vehicle Charging." Technology Analysis $\mathcal{E}$ Strategic Management 30 (1): 44-57. https://doi.org/10.1080/09537325.2017.1285397.

Arrow, Kenneth J., Partha Dasgupta, Lawrence H. Goulder, Kevin J. Mumford, and Kirsten Oleson. 2012. "Sustainability and the Measurement of Wealth." Environment and Development Economics 17 (3): 317-53. https://doi.org/10.1017/S1355770X12000137.

Arrow, Kenneth J., Paul R. Ehrlich, and Simon A. Levin. 2014. “Some Perspectives on Linked Ecosystems and Socioeconomic Systems." In Environment and Development Economics, edited by Scott Barrett, Karl-Göran Mäler, and Eric S. Maskin, 95-116. Oxford: Oxford University Press. https://doi.org/10.1093/acprof:oso/9780199677856.003.0003.

Arthur, W. Brian. 2015. “Complexity Economics: A Different Framework for Economic Thought." In Complexity and the Economy, edited by W. Brian Arthur, 1-29. New York: Oxford University Press. 
Asokan, Vivek Anand, Masaru Yarime, and Miguel Esteban. 2017. "Introducing Flexibility to Complex, Resilient Socio-Ecological Systems: A Comparative Analysis of Economics, Flexible Manufacturing Systems, Evolutionary Biology, and Supply Chain Management." Sustainability; Basel 9 (7): 1091. http://dx.doi.org.ezp-prod1.hul.harvard.edu/10.3390/su9071091.

Avelino, Flor. 2017. "Power in Sustainability Transitions: Analysing Power and (Dis)Empowerment in Transformative Change towards Sustainability: Power in Sustainability Transitions." Environmental Policy and Governance 27 (6): 505-20. https://doi.org/10.1002/eet.1777.

Avelino, Flor, and Julia M. Wittmayer. 2016. "Shifting Power Relations in Sustainability Transitions: A Multi-Actor Perspective." Journal of Environmental Policy \& Planning 18 (5): 628-49. https://doi.org/10.1080/1523908X.2015.1112259.

Bachrach, P., and M. Baratz. 1970. Power and Poverty: Theory and Practice. Oxford: Oxford University Press.

Baird, Julia, Ryan Plummer, Lisen Schultz, Derek Armitage, and Örjan Bodin. 2019. "How Does SocioInstitutional Diversity Affect Collaborative Governance of Social-Ecological Systems in Practice?" Environmental Management 63 (2): 200-214. https://doi.org/10.1007/s00267-018-1123-5.

Bakker, Sjoerd. 2014. "Actor Rationales in Sustainability Transitions - Interests and Expectations Regarding Electric Vehicle Recharging." Environmental Innovation and Societal Transitions 13 (December): 60-74. https://doi.org/10.1016/j.eist.2014.08.002.

Banzhaf, H. Spencer, Lala Ma, and Christopher Timmins. 2019. "Environmental Justice: Establishing Causal Relationships." Annual Review of Resource Economics 11 (1): 377-98.

https://doi.org/10.1146/annurev-resource-100518-094131.

Barbier, Edward B. 2019. “The Concept of Natural Capital." Oxford Review of Economic Policy 35 (1): 1436. https://doi.org/10.1093/oxrep/gry028.

Barbier, Edward B., and Jacob P. Hochard. 2019. "Poverty-Environment Traps." Environmental and Resource Economics 74 (3): 1239-71. https://doi.org/10.1007/s10640-019-00366-3.

Barnett, Jon, and W. Neil Adger. 2018. "Mobile Worlds: Choice at the Intersection of Demographic and Environmental Change." Annual Review of Environment and Resources 43 (1): 245-65. https://doi.org/10.1146/annurev-environ-102016-060952.

Bebbington, Anthony, Abdul-Gafaru Abdulai, Denise Humphreys Bebbington, Marja Hinfelaar, and Cynthia Sanborn. 2018. Governing Extractive Industries: Politics, Histories, Ideas. Oxford: Oxford University Press. https://doi.org/10.1093/oso/9780198820932.001.00010xford, UK: Oxford Univ. Press 
Beckert, Jens, and Richard Bronk. 2018. Uncertain Futures: Imaginaries, Narratives, and Calculation in the Economy. First edition. Oxford: Oxford University Press.

Bengtsson, Magnus, Eva Alfredsson, Maurie Cohen, Sylvia Lorek, and Patrick Schroeder. 2018.

"Transforming Systems of Consumption and Production for Achieving the Sustainable Development Goals: Moving beyond Efficiency." Sustainability Science 13 (6): 1533-47. https://doi.org/10.1007/s11625018-0582-1.

Benhabib, Jess, and Alberto Bisin. 2018. "Skewed Wealth Distributions: Theory and Empirics." Journal of Economic Literature 56 (4): 1261-91. https://doi.org/10.1257/jel.20161390.

Bennett, Elena M. 2017. "Research Frontiers in Ecosystem Service Science." Ecosystems; New York 20 (1): 31-37. http://dx.doi.org.ezp-prod1.hul.harvard.edu/10.1007/s10021-016-0049-0.

Betsill, Michele, Tabitha M. Benney, and Andrea K. Gerlak, eds. 2020. Agency in Earth System Governance. Cambridge University Press. https://doi.org/10.1017/9781108688277.

Bettencourt, Luís M. A., and Jasleen Kaur. 2011. “Evolution and Structure of Sustainability Science.” Proceedings of the National Academy of Sciences 108 (49): 19540-45.

https://doi.org/10.1073/pnas.1102712108.

Biermann, Frank, and Agni Kalfagianni. 2020. “Planetary Justice: A Research Framework.” Earth System Governance June. https://doi.org/10.1016/j.esg.2020.100049. In press.

Biermann, Frank, and Rakhyun E. Kim. 2020. "The Boundaries of the Planetary Boundary Framework: A Critical Appraisal of Approaches to Define a 'Safe Operating Space' for Humanity." Annual Review of Environment and Resources 45 (1). https://doi.org/10.1146/annurev-environ-012320-080337.

Biggs, Reinette, Line Gordon, Ciara Raudsepp-Hearne, Maja Schlüter, and Brian Walker. 2015. “Principle 3 - Manage Slow Variables and Feedbacks." In Principles for Building Resilience, edited by Reinette Biggs, Maja Schlüter, and Michael L. Schoon, 105-41. Cambridge: Cambridge University Press. https://doi.org/10.1017/CBO9781316014240.006.

Biggs, Reinette, Garry D. Peterson, and Juan C. Rocha. 2018. “The Regime Shifts Database: A Framework for Analyzing Regime Shifts in Social-Ecological Systems." Ecology and Society 23 (3): art9. https://doi.org/10.5751/ES-10264-230309.

Biggs, Reinette, Maja Schlüter, Duan Biggs, Erin L. Bohensky, Shauna BurnSilver, Georgina Cundill, Vasilis Dakos, et al. 2012. "Toward Principles for Enhancing the Resilience of Ecosystem Services." Annual Review of Environment and Resources 37 (1): 421-48. https://doi.org/10.1146/annurev-environ051211-123836. 
Binz, Christian, and Bernhard Truffer. 2017. "Global Innovation Systems - a Conceptual Framework for Innovation Dynamics in Transnational Contexts." Research Policy 46 (7): 1284-98.

https://doi.org/10.1016/j.respol.2017.05.012.

Bleischwitz, Raimund, Catalina Spataru, Stacy D. VanDeveer, Michael Obersteiner, Ester van der Voet, Corey Johnson, Philip Andrews-Speed, Tim Boersma, Holger Hoff, and Detlef P. van Vuuren. 2018. "Resource Nexus Perspectives towards the United Nations Sustainable Development Goals." Nature Sustainability 1 (12): 737-43. https://doi.org/10.1038/s41893-018-0173-2.

Blumm, Michael C., and Mary Christina Wood. 2017. "No Ordinary Lawsuit: Climate Change, Due Process, and the Public Trust Doctrine." American University Law Review 67 (1): 1-88.

Bobbio, Luigi. 2019. “Designing Effective Public Participation.” Policy and Society 38 (1): 41-57. https://doi.org/10.1080/14494035.2018.1511193.

Bodin, Örjan, Steven M. Alexander, Jacopo Baggio, Michele L. Barnes, Ramiro Berardo, Graeme S. Cumming, Laura E. Dee, et al. 2019. "Improving Network Approaches to the Study of Complex SocialEcological Interdependencies." Nature Sustainability 2 (7): 551-59. https://doi.org/10.1038/s41893-0190308-0.

Bodin, Örjan, María Mancilla García, and Garry Robins. 2020. "Reconciling Conflict and Cooperation in Environmental Governance: A Social Network Perspective." Annual Review of Environment and Resources 45 (1): annurev-environ-011020-064352. https://doi.org/10.1146/annurev-environ-011020064352.

Bohensky, Erin L., Louisa S. Evans, John M. Anderies, Duan Biggs, and Christo Fabricius. 2015. "Principle 4 - Foster Complex Adaptive Systems Thinking." In Principles for Building Resilience, edited by Reinette Biggs, Maja Schlüter, and Michael L. Schoon, 142-73. Cambridge: Cambridge University Press. https://doi.org/10.1017/CBO9781316014240.007.

Boonstra, Wiebren J. 2016. “Conceptualizing Power to Study Social-Ecological Interactions." Ecology and Society 21(1):21. http://www.jstor.org/stable/26270351.

Bornemann, Basil. 2019. "Nudging to Sustainability? Critical Reflections on Nudging from a Theoretically Informed Sustainability Perspective." In Handbook of Behavioural Change and Public Policy, by Holger Straßheim, Silke Beck, and Paul Burger, 209-26. Edward Elgar Publishing. https://doi.org/10.4337/9781785367854.00022.

Boston, Jonathan. 2017. Governing for the Future: Designing Democratic Institutions for a Better Tomorrow. First edition. Public Policy and Governance, volume 25. Bingley, UK: Emerald. 
Boyd, Robert, Peter J. Richerson, Ruth Meinzen-Dick, Tine De Moor, Matthew O. Jackson, Kristina M. Gjerde, Harriet Harden-Davies, et al. 2018. “Tragedy Revisited.” Science 362 (6420): 1236-41. https://doi.org/10.1126/science.aaw0911.

Brisbois, Marie Claire, Michelle Morris, and Rob de Loë. 2019. "Augmenting the IAD Framework to Reveal Power in Collaborative Governance - an Illustrative Application to Resource Industry Dominated Processes." World Development 120: 159-68. https://doi.org/10.1016/j.worlddev.2018.02.017.

Brondízio, Eduardo S., Elinor Ostrom, and Oran R. Young. 2009. "Connectivity and the Governance of Multilevel Social-Ecological Systems: The Role of Social Capital." Annual Review of Environment and Resources 34 (1): 253-78. https://doi.org/10.1146/annurev.environ.020708.100707.

Brown, Katrina. 2009. “Human Development and Environmental Governance: A Reality Check." In Governing Sustainability, edited by W. Neil Adger and Andrew Jordan, 32-52. Cambridge University Press. https://doi.org/10.1017/CBO9780511807756.004.

Brown, Katrina, W. Neil Adger, Patrick Devine-Wright, John M. Anderies, Stewart Barr, Francois Bousquet, Catherine Butler, Louisa Evans, Nadine Marshall, and Tara Quinn. 2019. “Empathy, Place and Identity Interactions for Sustainability." Global Environmental Change 56 (May): 11-17. https://doi.org/10.1016/j.gloenvcha.2019.03.003.

Brown, Katrina, and Elizabeth Westaway. 2011. "Agency, Capacity, and Resilience to Environmental Change: Lessons from Human Development, Well-Being, and Disasters." Annual Review of Environment and Resources 36 (1): 321-42. https://doi.org/10.1146/annurev-environ-052610-092905.

Bruijn, Karin de, Joost Buurman, Marjolein Mens, Ruben Dahm, and Frans Klijn. 2017. "Resilience in Practice: Five Principles to Enable Societies to Cope with Extreme Weather Events." Environmental Science E Policy 70 (April): 21-30. https://doi.org/10.1016/j.envsci.2017.02.001.

Burch, Sarah, Aarti Gupta, Cristina Y. A. Inoue, Agni Kalfagianni, Åsa Persson, Andrea K. Gerlak, Atsushi Ishii, et al. 2019. "New Directions in Earth System Governance Research." Earth System Governance 1 (January): 1-18. https://doi.org/10.1016/j.esg.2019.100006.

Caldecott, Ben. 2018. Stranded Assets and the Environment: Risk, Resilience and Opportunity. Routledge. https://doi.org/10.4324/9781315651606.

Caney, Simon. 2018. “Justice and Future Generations." Annual Review of Political Science 21 (1): 475-93. https://doi.org/10.1146/annurev-polisci-052715-111749.

Carpenter, Stephen R., Kenneth J. Arrow, Scott Barrett, Reinette Biggs, William A. Brock, Anne-Sophie Crepin, Gustav Engstrom, et al. 2012. "General Resilience to Cope with Extreme Events." Sustainability 
4 (12): 3248-59. https://doi.org/10.3390/su4123248.

Carpenter, Stephen R., William A. Brock, Carl Folke, Egbert H. van Nes, and Marten Scheffer. 2015. "Allowing Variance May Enlarge the Safe Operating Space for Exploited Ecosystems." Proceedings of the National Academy of Sciences 112 (46): 14384-89. https://doi.org/10.1073/pnas.1511804112.

Casey, Katherine. 2018. “Radical Decentralization: Does Community-Driven Development Work?” Annual Review of Economics 10 (1): 139-63. https://doi.org/10.1146/annurev-economics-080217-053339.

Cashore, Benjamin, Steven Bernstein, David Humphreys, Ingrid Visseren-Hamakers, and Katharine Rietig. 2019. “Designing Stakeholder Learning Dialogues for Effective Global Governance." Policy and Society 38 (1): 118-47. https://doi.org/10.1080/14494035.2019.1579505.

Chan, Gabriel, Robert Stavins, and Zou Ji. 2018. "International Climate Change Policy." Annual Review of Resource Economics 10: 335-60.

Chantarat, Sommarat, Andrew G. Mude, Christopher B. Barrett, and Calum G. Turvey. 2017. "Welfare Impacts of Index Insurance in the Presence of a Poverty Trap." World Development 94 (June): 119-38. https://doi.org/10.1016/j.worlddev.2016.12.044.

Chen, Bin, Rui Xiong, Hailong Li, Qie Sun, and Jin Yang. 2019. "Pathways for Sustainable Energy Transition." Journal of Cleaner Production 228 (August): 1564-71.

https://doi.org/10.1016/j.jclepro.2019.04.372.

Clark, William C., Pamela A. Matson, and Nancy M. Dickson. 2016. “Knowledge Systems for Sustainable Development: Special Feature Based on a Sackler Colloquium of the National Academy of Sciences." Proceedings of the National Academy of Sciences of the United States of America 113 (17): 45704622.

Clark, William C., Lorrae van Kerkhoff, Louis Lebel, and Gilberto C. Gallopin. 2016. "Crafting Usable Knowledge for Sustainable Development." Proceedings of the National Academy of Sciences 113 (17): 4570 78. https://doi.org/10.1073/pnas.1601266113.

Clark, William C., Thomas P. Tomich, Meine van Noordwijk, David Guston, Delia Catacutan, Nancy M. Dickson, and Elizabeth McNie. 2016. "Boundary Work for Sustainable Development: Natural Resource Management at the Consultative Group on International Agricultural Research (CGIAR)." Proceedings of the National Academy of Sciences 113 (17): 4615-22. https://doi.org/10.1073/pnas.0900231108.

Clement, Floriane. 2010. "Analysing Decentralised Natural Resource Governance: Proposition for a 'Politicised' Institutional Analysis and Development Framework." Policy Sciences 43 (2): 129-56. https://doi.org/10.1007/s11077-009-9100-8. 
Cohen, François, Cameron J. Hepburn, and Alexander Teytelboym. 2019. "Is Natural Capital Really Substitutable?" Annual Review of Environment and Resources 44 (1): 425-48.

https://doi.org/10.1146/annurev-environ-101718-033055.

Collins, Patricia Hill. 2015. “Intersectionality's Definitional Dilemmas." Annual Review of Sociology 41 (1): 1-20. https://doi.org/10.1146/annurev-soc-073014-112142.

Collins, Ross D., Noelle E. Selin, Olivier L. de Weck, and William C. Clark. 2017. "Using Inclusive Wealth for Policy Evaluation: Application to Electricity Infrastructure Planning in Oil-Exporting Countries." Ecological Economics 133: 23-34. https://doi.org///dx.doi.org/10.1016/j.ecolecon.2016.11.013.

Dahl, Robert A. 1957. “The Concept of Power.” Behavioral Science 2 (3): 201-215. https://doi.org/10.1002/bs.3830020303.

Dakos, Vasilis, Allyson Quinlan, Jacopo A. Baggio, Elena Bennett, Örjan Bodin, and Shauna Burnsilver. 2015. "Principle 2 - Manage Connectivity." In Principles for Building Resilience, edited by Reinette Biggs, Maja Schlüter, and Michael L. Schoon, 80-104. Cambridge: Cambridge University Press. https://doi.org/10.1017/CBO9781316014240.005.

Daly, Meaghan, and Lisa Dilling. 2019. “The Politics of 'Usable' Knowledge: Examining the Development of Climate Services in Tanzania." Climatic Change, October, 1-20. https://doi.org/10.1007/s10584-019-02510-w.

Dasgupta, Partha. 2004. Human Well-Being and the Natural Environment. 1st paperback, with Revised Appendix. Oxford: Oxford University Press.

—_ 2014. "Measuring the Wealth of Nations." Annual Review of Resource Economics 6 (1): 17-31. https://doi.org/10.1146/annurev-resource-100913-012358.

Dasgupta, Partha S. 2018. “Foreword to the Inclusive Wealth Report 2018." In Inclusive Wealth Report 2018 | Measuring Progress Towards Sustainability, edited by Shunsuke Managi and Pushpam Kumar, 1st ed., xxi-xxviii. London: Routledge. http://www.taylorfrancis.com/books/e/9781351002073.

Dasgupta, Partha S., and Paul R. Ehrlich. 2013. "Pervasive Externalities at the Population, Consumption, and Environment Nexus." Science 340 (6130): 324-28.

Dasgupta, Partha, Tapan Mitra, and Gerhard Sorger. 2019. "Harvesting the Commons." Environmental and Resource Economics 72 (3): 613-36. https://doi.org/10.1007/s10640-018-0221-4.

Deaton, Angus. 2013. The Great Escape: Health, Wealth, and the Origins of Inequality. Princeton, NJ: Princeton University Press. 
DeFries, Ruth, Erle C. Ellis, F. Stuart Chapin III, Pamela A. Matson, B. L. Turner II, Arun Agrawal, Paul J. Crutzen, et al. 2012. "Planetary Opportunities: A Social Contract for Global Change Science to Contribute to a Sustainable Future." Bioscience 62 (6): 603-6. https://doi.org/10.1525/bio.2012.62.6.11.

Díaz, Sandra, Sebsebe Demissew, Julia Carabias, Carlos Joly, Mark Lonsdale, Neville Ash, Anne Larigauderie, et al. 2015. “The IPBES Conceptual Framework - Connecting Nature and People.” Current Opinion in Environmental Sustainability, Open Issue, 14 (June): 1-16.

https://doi.org/10.1016/j.cosust.2014.11.002.

Díaz, Sandra, Unai Pascual, Marie Stenseke, Berta Martín-López, Robert T. Watson, Zsolt Molnár, Rosemary Hill, et al. 2018. “Assessing Nature's Contributions to People.” Science 359 (6373): 270-72. https://doi.org/10.1126/science.aap8826.

Díaz, Sandra, Josef Settele, Eduardo S. Brondízio, Hien T. Ngo, John Agard, Almut Arneth, Patricia Balvanera, et al. 2019. "Pervasive Human-Driven Decline of Life on Earth Points to the Need for Transformative Change." Science 366 (6471): eaax3100. https://doi.org/10.1126/science.aax3100.

Díaz-Reviriego, Isabel, E. Turnhout, and S. Beck. 2019. "Participation and Inclusiveness in the Intergovernmental Science-Policy Platform on Biodiversity and Ecosystem Services." Nature Sustainability 2 (6): 457-64. https://doi.org/10.1038/s41893-019-0290-6.

Dietz, Thomas. 2017. "Drivers of Human Stress on the Environment in the Twenty-First Century." Annual Review of Environment and Resources 42 (1): 189-213. https://doi.org/10.1146/annurev-environ110615-085440.

Downing, Andrea S, Avit Bhowmik, David Collste, Sarah E Cornell, Jonathan Donges, Ingo Fetzer, Tiina Häyhä, Jennifer Hinton, Steven Lade, and Wolf M Mooij. 2019. "Matching Scope, Purpose and Uses of Planetary Boundaries Science." Environmental Research Letters 14 (7): 073005.

https://doi.org/10.1088/1748-9326/ab22c9.

Dryzek, John S., André Bächtiger, Simone Chambers, Joshua Cohen, James N. Druckman, Andrea Felicetti, James S. Fishkin, et al. 2019. "The Crisis of Democracy and the Science of Deliberation." Science 363 (6432): 1144-46. https://doi.org/10.1126/science.aaw2694.

Dryzek, John S., and Jonathan Pickering. 2018. The Politics of the Anthropocene. Oxford: Oxford University Press. http://www.oxfordscholarship.com.ezpprod1.hul.harvard.edu/view/10.1093/oso/9780198809616.001.0001/oso-9780198809616.

Dryzek, John S., and Hayley Stevenson. 2014. Democratizing Global Climate Governance. Cambridge; New York: Cambridge University Press. 
Ekins, Paul, Joyeeta Gupta, and Pierre Boileau, eds. 2019. Global Environment Outlook 6. New York: Cambridge University Press.

Elsner, Wolfram. 2017. “Complexity Economics as Heterodoxy: Theory and Policy." Journal of Economic Issues 51 (4): 939-78. https://doi.org/10.1080/00213624.2017.1391570.

Enqvist, Johan P, Simon West, Vanessa A. Masterson, L. Jamila Haider, Uno Svedin, and Maria Tengö. 2018. "Stewardship as a Boundary Object for Sustainability Research: Linking Care, Knowledge and Agency." Landscape and Urban Planning 179 (November): 17-37.

https://doi.org/10.1016/j.landurbplan.2018.07.005.

Epstein, Graham, Jeremy Pittman, Steven M Alexander, Samantha Berdej, Thomas Dyck, Ursula Kreitmair, Kaitlyn J Rathwell, Sergio Villamayor-Tomas, Jessica Vogt, and Derek Armitage. 2015. "Institutional Fit and the Sustainability of Social-Ecological Systems." Current Opinion in Environmental Sustainability, Open Issue, 14 (June): 34-40. https://doi.org/10.1016/j.cosust.2015.03.005.

Eriksen, Siri H., Andrea J. Nightingale, and Hallie Eakin. 2015. "Reframing Adaptation: The Political Nature of Climate Change Adaptation." Global Environmental Change 35 (November): 523-33.

https://doi.org/10.1016/j.gloenvcha.2015.09.014.

Estevadeordal, Antoni, and Louis W Goodman, eds. 2017. 21st Century Cooperation: Regional Public Goods, Global Governance, and Sustainable Development. London; New York: Routledge. http://public.ebookcentral.proquest.com/choice/publicfullrecord.aspx?p=4862621.

Evans. 2019. "Competencies and Pedagogies for Sustainability Education: A Roadmap for Sustainability Studies Program Development in Colleges and Universities." Sustainability 11 (19): 5526.

https://doi.org/10.3390/su11195526.

Evans, Alice. 2018. "Politicising Inequality: The Power of Ideas.” World Development 110 (October): 36072. https://doi.org/10.1016/j.worlddev.2018.06.006.

Evans, Geoff, and Liam Phelan. 2016. “Transition to a Post-Carbon Society: Linking Environmental Justice and Just Transition Discourses." Energy Policy 99 (December): 329-39.

https://doi.org/10.1016/j.enpol.2016.05.003.

Fagerberg, Jan. 2018. "Mobilizing Innovation for Sustainability Transitions: A Comment on Transformative Innovation Policy." Research Policy 47 (9): 1568-76.

https://doi.org/10.1016/j.respol.2018.08.012.

Farmer, J. D., C. Hepburn, M. C. Ives, T. Hale, T. Wetzer, P. Mealy, R. Rafaty, S. Srivastav, and R. Way. 2019. "Sensitive Intervention Points in the Post-Carbon Transition." Science 364 (6436): 132-34. 
https://doi.org/10.1126/science.aaw7287.

Farrell, Justin. 2019. "The Growth of Climate Change Misinformation in US Philanthropy: Evidence from Natural Language Processing." Environmental Research Letters 14 (3): 034013.

https://doi.org/10.1088/1748-9326/aaf939.

Ferreira, Leonardo L. G., and Adriano D. Andricopulo. 2019. "Drugs and Vaccines in the 21st Century for Neglected Diseases." The Lancet Infectious Diseases 19 (2): 125-27. https://doi.org/10.1016/S14733099(19)30005-2.

Fischhoff, Baruch. 2019. "Evaluating Science Communication." Proceedings of the National Academy of Sciences 116 (16): 7670-75. https://doi.org/10.1073/pnas.1805863115.

Folke, Carl. 2016. “Resilience (Republished)." Ecology and Society 21 (4): art44.

https://doi.org/10.5751/ES-09088-210444.

Folke, Carl, Henrik Österblom, Jean-Baptiste Jouffray, Eric F. Lambin, W. Neil Adger, Marten Scheffer, Beatrice I. Crona, et al. 2019. "Transnational Corporations and the Challenge of Biosphere Stewardship." Nature Ecology \& Evolution 3 (September): 1396-1403. https://doi.org/10.1038/s41559019-0978-z.

Forsyth, Tim. 2003. Critical Political Ecology: The Politics of Environmental Science. London; New York: Routledge.

Foucault, Michel. 1979. Discipline and Punish: The Birth of the Prison. Social Theory. New York: Vintage Books.

Foxon, Timothy J. 2011. “A Coevolutionary Framework for Analysing a Transition to a Sustainable Low Carbon Economy." Ecological Economics 70 (12): 2258-67. https://doi.org/10.1016/j.ecolecon.2011.07.014.

Frye, Northrop. 1957. Anatomy of Criticism: Four Essays. Princeton, NJ: Princeton University Press.

Fuenfschilling, Lea, and Christian Binz. 2018. “Global Socio-Technical Regimes.” Research Policy 47 (4): 735-49. https://doi.org/10.1016/j.respol.2018.02.003.

Galaitsi, Stephanie, Jason Veysey, and Annette Huber-Lee. 2018. "Where Is the Added Value? A Review of the Water-Energy-Food Nexus Literature." SEI Working Paper. Stockholm: Stockholm Environment Institute. https://www.sei.org/publications/added-value-review-water-energy-food-nexusliterature/.

Galasso, Alberto, Matthew Mitchell, and Gabor Virag. 2018. "A Theory of Grand Innovation Prizes." Research Policy 47 (2): 343-62. https://doi.org/10.1016/j.respol.2017.11.009. 
Ganz, Marshall. 2009. Why David Sometimes Wins: Leadership, Organization, and Strategy in the California Farm Worker Movement. Oxford; New York: Oxford University Press.

http://nrs.harvard.edu/urn-3:hul.ebookbatch.GEN_batch:EDZ000008281120160621.

Gaventa, John. 1980. Power and Powerlessness: Quiescence and Rebellion in an Appalachian Valley. Urbana: University of Illinois Press.

_ _ 2020. "Applying Power Analysis: Using the 'Powercube' to Explore Forms, Levels and Spaces." In Power, Empowerment and Social Change, edited by Rosemary McGee and Jethro Pettit, 117-38. Rethinking Development. London: Routledge.

Geels, Frank W. 2019. “Socio-Technical Transitions to Sustainability: A Review of Criticisms and Elaborations of the Multi-Level Perspective." Current Opinion in Environmental Sustainability, Open Issue 2019, 39 (August): 187-201. https://doi.org/10.1016/j.cosust.2019.06.009.

Geels, Frank W. 2020. "Micro-Foundations of the Multi-Level Perspective on Socio-Technical Transitions: Developing a Multi-Dimensional Model of Agency through Crossovers between Social Constructivism, Evolutionary Economics and Neo-Institutional Theory." Technological Forecasting and Social Change 152 (March): 119894. https://doi.org/10.1016/j.techfore.2019.119894.

Geels, Frank W., Andy McMeekin, Josephine Mylan, and Dale Southerton. 2015. "A Critical Appraisal of Sustainable Consumption and Production Research: The Reformist, Revolutionary and Reconfiguration Positions." Global Environmental Change 34 (September): 1-12.

https://doi.org/10.1016/j.gloenvcha.2015.04.013.

Geels, Frank W., Benjamin K. Sovacool, Tim Schwanen, and Steve Sorrell. 2017. “Sociotechnical Transitions for Deep Decarbonization." Science 357 (6357): 1242-44.

https://doi.org/10.1126/science.aao3760.

Gerlak, Andrea K., Thomas R. Eimer, Marie-Claire Brisbois, Luuk Schmitz Mills-Novoa, Luimers Jorrit, and Abernethy Paivi. 2019. "Power(Ful) and Power(Less): A Review of Power in the ESG-Agency Scholarship." In Agency in Earth System Governance. Earth System Governance Series. Cambridge: Cambridge University Press. www.cambridge.org/9781108484053.

Gerlak, Andrea K., Tanya Heikkila, Sharon L. Smolinski, Dave Huitema, and Derek Armitage. 2018. "Learning Our Way out of Environmental Policy Problems: A Review of the Scholarship." Policy Sciences 51 (3): 335-71. https://doi.org/10.1007/s11077-017-9278-0.

Ghosh, Bipashyee, and Johan Schot. 2019. “Towards a Novel Regime Change Framework: Studying Mobility Transitions in Public Transport Regimes in an Indian Megacity." Energy Research \& Social Science 51 (May): 82-95. https://doi.org/10.1016/j.erss.2018.12.001. 
Giangrande, Naresh, Rehema M. White, May East, Ross Jackson, Tim Clarke, Michel Saloff Coste, and Gil Penha-Lopes. 2019. "A Competency Framework to Assess and Activate Education for Sustainable Development: Addressing the UN Sustainable Development Goals 4.7 Challenge." Sustainability 11 (10): 2832. https://doi.org/10.3390/su11102832.

Gilarranz, Luis J., Bronwyn Rayfield, Gustavo Liñán-Cembrano, Jordi Bascompte, and Andrew Gonzalez. 2017. "Effects of Network Modularity on the Spread of Perturbation Impact in Experimental Metapopulations." Science 357 (6347): 199-201. https://doi.org/10.1126/science.aal4122.

Gollier, Christian, and James K. Hammitt. 2014. “The Long-Run Discount Rate Controversy.” Annual Review of Resource Economics 6 (1): 273-95. https://doi.org/10.1146/annurev-resource-100913-012516.

Griffiths, Jesse. 2018. “Financing the Sustainable Development Goals (SDGs).” Development 61 (1): 62-67. https://doi.org/10.1057/s41301-018-0178-1.

Grillos, Tara. 2019. Deliberation Improves Collective Decision Making: Experimental Evidence from Kenya. Paper presented at the $115^{\text {th }}$ Annual Conference of the American Political Science Association, Washington, DC. Aug 29-Sept. 1.

https://www.taragrillos.com/uploads/1/1/7/1/117111931/grillos_2019_deliberation_improves_collective_ decisions.pdf.

Haberl, Helmut, Dominik Wiedenhofer, Stefan Pauliuk, Fridolin Krausmann, Daniel B. Müller, and Marina Fischer-Kowalski. 2019. "Contributions of Sociometabolic Research to Sustainability Science." Nature Sustainability 2 (3): 173-84. https://doi.org/10.1038/s41893-019-0225-2.

Hagstrom, George I., and Simon A. Levin. 2017. "Marine Ecosystems as Complex Adaptive Systems: Emergent Patterns, Critical Transitions, and Public Goods." Ecosystems 20 (3): 458-76.

http://dx.doi.org.ezp-prod1.hul.harvard.edu/10.1007/s10021-017-0114-3.

Hajer, Maarten, and Wytske Versteeg. 2019. "Imagining the Post-Fossil City: Why Is It So Difficult to Think of New Possible Worlds?” Territory, Politics, Governance 7 (2): 122-34.

https://doi.org/10.1080/21622671.2018.1510339.

Hajjar, Reem, and Johan A. Oldekop. 2018. "Research Frontiers in Community Forest Management." Current Opinion in Environmental Sustainability, Environmental change issues 2018, 32 (June): 119-25. https://doi.org/10.1016/j.cosust.2018.06.003.

Hale, Thomas. 2020. "Transnational Actors and Transnational Governance in Global Environmental Politics." Annual Review of Political Science 23: 12.1-12.18. 
Hamann, Maike, Kevin Berry, Tomas Chaigneau, Tracie Curry, Robert Heilmayr, Patrik J.G. Henriksson, Jonas Hentati-Sundberg, et al. 2018. "Inequality and the Biosphere." Annual Review of Environment and Resources 43 (1): 61-83. https://doi.org/10.1146/annurev-environ-102017-025949.

Hamilton, Kirk E., John F. Helliwell, and Michael Woolcock. 2016. “Social Capital, Trust, and Well-Being in the Evaluation of Wealth." WPS7707. The World Bank.

http://documents.worldbank.org/curated/en/249031468195550873/Social-capital-trust-and-wellbeing-in-the-evaluation-of-wealth.

Hansen, Ulrich Elmer, Ivan Nygaard, Henny Romijn, Anna Wieczorek, Linda M. Kamp, and Laurens Klerkx. 2018. "Sustainability Transitions in Developing Countries: Stocktaking, New Contributions and a Research Agenda." Environmental Science \& Policy 84 (June): 198-203.

https://doi.org/10.1016/j.envsci.2017.11.009.

Haugaard, Mark. 2002. Power: A Reader. Manchester: Manchester University Press.

Hausknost, Daniel, and Willi Haas. 2019. “The Politics of Selection: Towards a Transformative Model of Environmental Innovation.” Sustainability 11 (2): 506. https://doi.org/10.3390/su11020506.

Heilmayr, Robert, and Eric F. Lambin. 2016. "Impacts of Nonstate, Market-Driven Governance on Chilean Forests." Proceedings of the National Academy of Sciences 113 (11): 2910-15. https://doi.org/10.1073/pnas.1600394113.

Henderson, Rebecca. 2015. "Making the Business Case for Environmental Sustainability." In Leading Sustainable Change: An Organizational Perspective, edited by R Henderson, R Gulati, ML Tushman, 2247. Oxford: Oxford University Press.

http://www.oxfordscholarship.com/view/10.1093/acprof:oso/9780198704072.001.0001/acprof9780198704072-chapter-2.

_- 2020. Reimagining Capitalism in a World on Fire. New York: PublicAffairs.

Henry, Adam Douglas, and Björn Vollan. 2014. "Networks and the Challenge of Sustainable Development." Annual Review of Environment and Resources 39 (1): 583-610.

https://doi.org/10.1146/annurev-environ-101813-013246.

Hess, Charlotte. 2012. “The Unfolding of the Knowledge Commons.” Text. May 2012. https://www.ingentaconnect.com/content/stair/stair/2012/00000008/00000001/art00003.

Hess, Charlotte, and Elinor Ostrom, eds. 2007. Understanding Knowledge as a Commons: From Theory to Practice. Cambridge, MA: MIT Press. 
Hicks, Christina C., Arielle Levine, Arun Agrawal, Xavier Basurto, Sara J. Breslow, Courtney Carothers, Susan Charnley, et al. 2016. “Engage Key Social Concepts for Sustainability.” Science 352 (6281): 38-40. https://doi.org/10.1126/science.aad4977.

Hirsch, Shana Lee, and Jerrold Long. 2020. "Adaptive Epistemologies: Conceptualizing Adaptation to Climate Change in Environmental Science." Science, Technology, \& Human Values, January.

https://doi.org/10.1177/0162243919898517.

Hoekstra, Arjen Y., Rianne Bredenhoff-Bijlsma, and Maarten S. Krol. 2018. “The Control versus Resilience Rationale for Managing Systems under Uncertainty.” Environmental Research Letters 13 (10): 103002. https://doi.org/10.1088/1748-9326/aadf95.

Hölscher, Katharina, Julia M. Wittmayer, and Derk Loorbach. 2018. “Transition versus Transformation: What's the Difference?" Environmental Innovation and Societal Transitions 27 (June): 1-3.

https://doi.org/10.1016/j.eist.2017.10.007.

Homayounfar, Mehran, Rachata Muneepeerakul, John M. Anderies, and Chitsomanus P. Muneepeerakul. 2018. "Linking Resilience and Robustness and Uncovering Their Trade-Offs in Coupled Infrastructure Systems." Earth System Dynamics 9 (4): 1159-68. https://doi.org/10.5194/esd-91159-2018.

Hull, Vanessa, and Jianguo Liu. 2018. “Telecoupling: A New Frontier for Global Sustainability.” Ecology and Society 23 (4): art11. https://doi.org/10.5751/ES-10494-230441.

ICSU, and ISSC. 2015. "Review of Targets for the Sustainable Development Goals: The Science Perspective." Paris: International Council for Science. https://council.science/publications/review-oftargets-for-the-sustainable-development-goals-the-science-perspective-2015/.

Ikeda, Shinya, and Shunsuke Managi. 2019. "Future Inclusive Wealth and Human Well-Being in Regional Japan: Projections of Sustainability Indices Based on Shared Socioeconomic Pathways." Sustainability Science; Dordrecht 14 (1): 147-58. http://dx.doi.org.ezpprod1.hul.harvard.edu/10.1007/s11625-018-0589-7.

IPBES, Sandra Díaz, J Settele, Eduardo Brondízio, H Ngo, M Guèze, J Agard, et al. 2019. “Summary for Policymakers of the Global Assessment Report on Biodiversity and Ecosystem Services of the Intergovernmental Science-Policy Platform on Biodiversity and Ecosystem Services." Bonn, Germany: IPBES secretariat. https://www.ipbes.net/global-assessment-report-biodiversity-ecosystem-services.

IPCC. 2018. "Global Warming of $1.5^{\circ} \mathrm{C}$." Geneva: World Meteorological Organization/United Nations Environment Program. http://www.ipcc.ch/report/sr15/. 
Irwin, Elena G., Sathya Gopalakrishnan, and Alan Randall. 2016. "Welfare, Wealth, and Sustainability." Annual Review of Resource Economics 8 (1): 77-98. https://doi.org/10.1146/annurev-resource-100815095351.

Jabbour, Jason, and Christian Flachsland. 2017. "40 Years of Global Environmental Assessments: A Retrospective Analysis." Environmental Science \& Policy 77 (November): 193-202.

https://doi.org/10.1016/j.envsci.2017.05.001.

Jasanoff, Sheila. 2018. “Just Transitions: A Humble Approach to Global Energy Futures.” Energy Research $\mathcal{E}$ Social Science, Energy and the Future, 35 (January): 11-14.

https://doi.org/10.1016/j.erss.2017.11.025.

Jasanoff, Sheila, and Sang-Hyun Kim. 2015. Dreamscapes of Modernity: Sociotechnical Imaginaries and the Fabrication of Power. Chicago; London: The University of Chicago Press. http://nrs.harvard.edu/urn3:hul.ebookbatch.GEN_batch:EDZ000128427620160622.

Johnson, David R., and Nathan B. Geldner. 2019. "Contemporary Decision Methods for Agricultural, Environmental, and Resource Management and Policy." Annual Review of Resource Economics 11 (1): 1941. https://doi.org/10.1146/annurev-resource-100518-094020.

Jordan, Andrew, Dave Huitema, Jonas J. Schoenefeld, Harro van Asselt, and Johanna Forster. 2018. “Governing Climate Change Polycentrically: Setting the Scene." In Governing Climate Change, edited by Andrew Jordan, Dave Huitema, Harro van Asselt, and Johanna Forster, 1st-25th ed., 359-83. Cambridge University Press. https://doi.org/10.1017/9781108284646.021.

Jumbri, Isma Addi, and Shunsuke Managi. 2020. “Inclusive Wealth with Total Factor Productivity: Global Sustainability Measurement." Global Sustainability 3: e5. https://doi.org/10.1017/sus.2020.1.

Kabeer, Naila. 1999. “Resources, Agency, Achievements: Reflections on the Measurement of Women's Empowerment." Development and Change 30 (3): 435-64. https://doi.org/10.1111/1467-7660.00125.

Kanger, Laur, and Johan Schot. 2019. "Deep Transitions: Theorizing the Long-Term Patterns of SocioTechnical Change." Environmental Innovation and Societal Transitions 32 (September): 7-21. https://doi.org/10.1016/j.eist.2018.07.006.

Kanie, Norichika, and Frank Biermann. 2017. Governing Through Goals: Sustainable Development Goals as Governance Innovation. Earth System Governance. Cambridge, MA: MIT Press. https://muse-jhuedu.ezp-prod1.hul.harvard.edu/book/52006/.

Kashwan, Prakash, Lauren M. MacLean, and Gustavo A. García-López. 2019. "Rethinking Power and Institutions in the Shadows of Neoliberalism: (An Introduction to a Special Issue of World 
Development)." World Development 120 (August): 133-46.

https://doi.org/10.1016/j.worlddev.2018.05.026.

Kates, Robert W. 2011. "What Kind of a Science Is Sustainability Science?" Proceedings of the National Academy of Sciences 108 (49): 19449-50. https://doi.org/10.1073/pnas.1116097108.

Kattel, Rainer, and Mariana Mazzucato. 2018. "Mission-Oriented Innovation Policy and Dynamic Capabilities in the Public Sector." Industrial and Corporate Change 27 (5): 787-801. https://doi.org/10.1093/icc/dty032.

Keohane, Robert O., and David G. Victor. 2016. "Cooperation and Discord in Global Climate Policy." Nature Climate Change; London 6 (6): 570-75. http://dx.doi.org.ezpprod1.hul.harvard.edu/10.1038/nclimate2937.

Kerkhoff, Lorrae van, and Louis Lebel. 2015. "Coproductive Capacities: Rethinking Science-Governance Relations in a Diverse World." Ecology and Society 20 (1): art14. https://doi.org/10.5751/ES-07188-200114.

Keys, Patrick W., Victor Galaz, Michelle Dyer, Nathanial Matthews, Carl Folke, Magnus Nyström, and Sarah E. Cornell. 2019. “Anthropocene Risk." Nature Sustainability 2: 667-673.

https://doi.org/10.1038/s41893-019-0327-x.

Köhler, Jonathan, Frank W. Geels, Florian Kern, Jochen Markard, Anna Wieczorek, Floortje Alkemade, Flor Avelino, et al. 2019. "An Agenda for Sustainability Transitions Research: State of the Art and Future Directions." Environmental Innovation and Societal Transitions (January): 1-32. https://doi.org/10.1016/j.eist.2019.01.004.

Kohler, Pia M. 2020. Science Advice and Global Environmental Governance: Expert Institutions and the Implementation of International Environmental Treaties. London: Anthem Press. http://search.ebscohost.com/login.aspx?direct=true\&scope=site\&db=nlebk\&db=nlabk\&AN=2317844. Kousky, Carolyn. 2019. “The Role of Natural Disaster Insurance in Recovery and Risk Reduction.” Annual Review of Resource Economics 11 (1): 399-418. https://doi.org/10.1146/annurev-resource-100518094028.

Kraker, Joop de. 2017. "Social Learning for Resilience in Social-Ecological Systems." Current Opinion in Environmental Sustainability 28 (October): 100-107. https://doi.org/10.1016/j.cosust.2017.09.002.

Lambin, Eric F., and Tannis Thorlakson. 2018. "Sustainability Standards: Interactions between Private Actors, Civil Society, and Governments." Annual Review of Environment and Resources 43 (1): null. https://doi.org/10.1146/annurev-environ-102017-025931. 
Lange, Glenn-Marie, Quentin Wodon, and Kevin Carey. 2018. The Changing Wealth of Nations 2018:

Building a Sustainable Future. The World Bank. https://doi.org/10.1596/978-1-4648-1046-6.

Laurent, Éloi. 2018. Measuring Tomorrow: Accounting for Well-Being, Resilience, and Sustainability in the Twenty-First Century. Princeton, NJ: Princeton University Press.

Leach, Melissa, Ian Scoones, and Andy Stirling. 2010. Dynamic Sustainabilities: Technology, Environment, Social Justice. Pathways to Sustainability Series. London; Washington, DC: Earthscan.

LeBlanc, David. 2015. “Towards Integration at Last? The Sustainable Development Goals as a Network of Targets." Sustainable Development 23 (3): 176-87. https://doi.org/10.1002/sd.1582.

Leiserowitz, Anthony A., Robert W. Kates, and Thomas M. Parris. 2006. "Sustainability Values, Attitudes, and Behaviors: A Review of Multinational and Global Trends." Annual Review of Environment and Resources 31 (1): 413-44. https://doi.org/10.1146/annurev.energy.31.102505.133552.

Levin, Simon. 2003. "Complex Adaptive Systems: Exploring the Known, the Unknown and the Unknowable." Bulletin of the American Mathematical Society 40 (1): 3-19. https://doi.org/10.1090/S02730979-02-00965-5.

Levin, Simon, Tasos Xepapadeas, Anne-Sophie Crépin, Jon Norberg, Aart de Zeeuw, Carl Folke, Terry Hughes, and Kenneth Arrow. 2012. "Social-Ecological Systems as Complex Adaptive Systems: Modeling and Policy Implications." Environment and Development Economics 18 (2): 111-32. http://dx.doi.org.ezpprod1.hul.harvard.edu/10.1017/S1355770X12000460.

Lim, Michelle, Peter Søgaard Jørgensen, and Carina Wyborn. 2018. “Reframing the Sustainable Development Goals to Achieve Sustainable Development in the Anthropocene-a Systems Approach." Ecology and Society 23 (3): art22. https://doi.org/10.5751/ES-10182-230322.

Lintsen, Harry, Frank Veraart, Jan-Pieter Smits, and John Grin. 2018. Well-Being, Sustainability and Social Development: The Netherlands 1850-2050. Cham: Springer International Publishing. https://doi.org/10.1007/978-3-319-76696-6.

Liu, Jianguo, Vanessa Hull, H. Charles J. Godfray, David Tilman, Peter Gleick, Holger Hoff, Claudia PahlWostl, et al. 2018. "Nexus Approaches to Global Sustainable Development." Nature Sustainability 1 (9): 466-76. https://doi.org/10.1038/s41893-018-0135-8.

Liu, Junguo, Kamaljit S. Bawa, Thomas P. Seager, Ganquan Mao, Ding Ding, Janice Ser Huay Lee, and Janet K. Swim. 2019. “On Knowledge Generation and Use for Sustainability.” Nature Sustainability 2 (2): 80. https://doi.org/10.1038/s41893-019-0229-y. 
Liu, Teng, and Theodore Kahn. 2017. "Regional Public Goods Cooperation: An Inductive Approach to Measuring Regional Public Goods." In 21st Century Cooperation: Regional Public Goods, Global Governance, and Sustainable Development, edited by Antoni Estevadeordal and Louis W Goodman, 3-13. London; New York: Routledge. http://public.ebookcentral.proquest.com/choice/publicfullrecord.aspx? $\mathrm{p}=4862621$.

Loorbach, Derk, Niki Frantzeskaki, and Flor Avelino. 2017. "Sustainability Transitions Research: Transforming Science and Practice for Societal Change." Annual Review of Environment and Resources 42 (1): 599-626. https://doi.org/10.1146/annurev-environ-102014-021340.

Loste, Natalia, Esther Roldán, and Beatriz Giner. 2019. “Is Green Chemistry a Feasible Tool for the Implementation of a Circular Economy?" Environmental Science and Pollution Research, 27 (December): 6215-27. https://doi.org/10.1007/s11356-019-07177-5.

Lubchenco, Jane, Elizabeth B. Cerny-Chipman, Jessica N. Reimer, and Simon A. Levin. 2016. “The Right Incentives Enable Ocean Sustainability Successes and Provide Hope for the Future." Proceedings of the National Academy of Sciences 113 (51): 14507-14. https://doi.org/10.1073/pnas.1604982113.

Lukes, Steven. 1974. Power: A Radical View. Studies in Sociology (Macmillan Press). Basingstoke, UK: Macmillan.

Mach, Katharine J., and Christopher B. Field. 2017. "Toward the next Generation of Assessment." Annual Review of Environment and Resources 42 (1): 569-97. https://doi.org/10.1146/annurev-environ102016-061007.

Managi, Shunsuke, and Pushpam Kumar, eds. 2018. Inclusive Wealth Report 2018 / Measuring Progress Towards Sustainability. 1st ed. London: Routledge. http://www.taylorfrancis.com/books/e/9781351002073.

Mann, Michael. 2012. The Sources of Social Power: Volume 3, Global Empires and Revolution, 1890-1945. Cambridge; New York: Cambridge University Press.

March, James G., and Johan P. Olsen. 2011. "The Logic of Appropriateness." In The Oxford Handbook of Political Science, edited by R. Goodin, 478-497. Oxford, UK: Oxford Univ. Press.

Markard, Jochen, Frank W. Geels, and Rob Raven. 2020. "Challenges in the Acceleration of Sustainability Transitions." Environmental Research Letters, May. https://doi.org/10.1088/17489326/ab9468.

Markard, Jochen, Rob Raven, and Bernhard Truffer. 2012. "Sustainability Transitions: An Emerging Field of Research and Its Prospects." Research Policy, Special Section on Sustainability Transitions, 41 
(6): 955-67. https://doi.org/10.1016/j.respol.2012.02.013.

Marquis, Christopher, Michael W. Toffel, and Yanhua Zhou. 2016. "Scrutiny, Norms, and Selective Disclosure: A Global Study of Greenwashing." Organization Science 27 (2): 483-504.

https://doi.org/10.1287/orsc.2015.1039.

Marshall, N. A., S. E. Park, W. N. Adger, K. Brown, and S. M. Howden. 2012. "Transformational Capacity and the Influence of Place and Identity." Environmental Research Letters 7 (3): 1-9. https://doi.org/10.1088/1748-9326/7/3/034022.

Martín-López, Berta, María R. Felipe-Lucia, Elena M. Bennett, Albert Norström, Garry Peterson, Tobias Plieninger, Christina C. Hicks, et al. 2019. "A Novel Telecoupling Framework to Assess Social Relations across Spatial Scales for Ecosystem Services Research." Journal of Environmental Management 241 (July): 251-63. https://doi.org/10.1016/j.jenvman.2019.04.029.

May, Robert M., Simon A. Levin, and George Sugihara. 2008. “Complex Systems: Ecology for Bankers.” Nature; London 451 (7181): 893-95. http://dx.doi.org.ezp-prod1.hul.harvard.edu/10.1038/451893a.

Mazzucato, Mariana. 2018. The Value of Everything: Making and Taking in the Global Economy. First US edition. New York: PublicAffairs.

McGee, Rosemary, and Jethro Pettit, eds. 2019. Power, Empowerment and Social Change. Milton: Routledge. https://doi.org/10.4324/9781351272322.

McGinnis, Michael D., and Elinor Ostrom. 2014. "Social-Ecological System Framework: Initial Changes and Continuing Challenges." Ecology and Society 19 (2): art30. https://doi.org/10.5751/ES-06387-190230. McKibben, Bill. 2019. "Money Is the Oxygen on Which the Fire of Global Warming Burns." The New Yorker, September 17, 2019. https://www-newyorker-com.ezp-prod1.hul.harvard.edu/news/dailycomment/money-is-the-oxygen-on-which-the-fire-of-global-warming-burns?verso=true.

McNeill, John Robert. 2016. The Great Acceleration: An Environmental History of the Anthropocene Since 1945. Cambridge, MA: Belknap Press of Harvard University Press.

Menton, Mary, Carlos Larrea, Sara Latorre, Joan Martinez-Alier, Mika Peck, Leah Temper, and Mariana Walter. 2020. "Environmental Justice and the SDGs: From Synergies to Gaps and Contradictions." Sustainability Science, April. https://doi.org/10.1007/s11625-020-00789-8.

Merli, Roberto, Michele Preziosi, and Alessia Acampora. 2018. "How Do Scholars Approach the Circular Economy? A Systematic Literature Review." Journal of Cleaner Production 178 (March): 703-22. https://doi.org/10.1016/j.jclepro.2017.12.112. 
Meyfroidt, P., R. Roy Chowdhury, A. de Bremond, E.C. Ellis, K.-H. Erb, T. Filatova, R.D. Garrett, et al. 2018. "Middle-Range Theories of Land System Change." Global Environmental Change 53 (November): 52-67. https://doi.org/10.1016/j.gloenvcha.2018.08.006.

Michaels, David. 2020. The Triumph of Doubt: Dark Money and the Science of Deception. Oxford: Oxford University Press. https://ebookcentral-proquest-com.ezp-prod1.hul.harvard.edu/lib/harvardebooks/detail.action?docID $=6006824$.

Middeldorp, Nick, and Philippe Le Billon. 2019. "Deadly Environmental Governance: Authoritarianism, Eco-Populism, and the Repression of Environmental and Land Defenders." Annals of the American Association of Geographers 109 (2): 324-37. https://doi.org/10.1080/24694452.2018.1530586.

Mikulewicz, Michael. 2020. "The Discursive Politics of Adaptation to Climate Change." Annals of the American Association of Geographers. https://doi.org/10.1080/24694452.2020.1736981. In press.

Milanovic, Branko. 2018. “Towards an Explanation of Inequality in Premodern Societies: The Role of Colonies, Urbanization, and High Population Density." The Economic History Review 71 (4): 1029-47. https://doi.org/10.1111/ehr.12613.

Milfont, Taciano L., Paul G. Bain, Yoshihisa Kashima, Victor Corral-Verdugo, Carlota Pasquali, LarsOlof Johansson, Yanjun Guan, et al. 2018. “On the Relation between Social Dominance Orientation and Environmentalism: A 25-Nation Study.” Social Psychological and Personality Science 9 (7): 802-14. https://doi.org/10.1177/1948550617722832.

Milkoreit, Manjana, Jennifer Hodbod, Jacopo Baggio, Karina Benessaiah, Rafael Calderón-Contreras, Jonathan F. Donges, Jean-Denis Mathias, Juan Carlos Rocha, Michael Schoon, and Saskia E. Werners. 2018. "Defining Tipping Points for Social-Ecological Systems Scholarship - an Interdisciplinary Literature Review." Environmental Research Letters 13 (3): 033005. https://doi.org/10.1088/17489326/aaaa75.

Mitchell, Ronald B., Liliana B. Andonova, Mark Axelrod, Jörg Balsinger, Thomas Brenauer, Jessica F. Green, James Hollway, Rakhyun E. Kim, and Jean-Frédéric Morin. 2020. "What We Know (and Could Know) About International Environmental Agreements" Global Environmental Politics 20 (1): 103-121.

Mitchell, Ronald B., and Charli Carpenter. 2019. "Norms for the Earth: Changing the Climate on 'Climate Change."' Journal of Global Security Studies 4: 413-29. https://doi.org/10.1093/jogss/ogz 006.

Miteva, Daniela A., Colby J. Loucks, and Subhrendu K. Pattanayak. 2015. "Social and Environmental Impacts of Forest Management Certification in Indonesia." PLOS ONE 10 (7): e0129675. https://doi.org/10.1371/journal.pone.0129675. 
Moon, Suerie. 2019. "Power in Global Governance: An Expanded Typology from Global Health.” Globalization and Health 15 (1): 74. https://doi.org/10.1186/s12992-019-0515-5.

Moran, Emilio F. 2010. Environmental Social Science: Human-Environment Interactions and Sustainability. Malden, MA: Wiley-Blackwell.

Moritz, Mark, Roy Behnke, Christine M. Beitl, Rebecca Bliege Bird, Rafael Morais Chiaravalloti, Julia K. Clark, Stefani A. Crabtree, et al. 2018. "Emergent Sustainability in Open Property Regimes." Proceedings of the National Academy of Sciences 115 (51): 12859-67.

https://doi.org/10.1073/pnas.1812028115.

Morrison, T. H., W. N. Adger, K. Brown, M. C. Lemos, D. Huitema, J. Phelps, L. Evans, et al. 2019. “The Black Box of Power in Polycentric Environmental Governance." Global Environmental Change 57 (July): 101934. https://doi.org/10.1016/j.gloenvcha.2019.101934.

Morrison, T.H. 2017. "Evolving Polycentric Governance of the Great Barrier Reef." Proceedings of the National Academy of Sciences of the United States of America 114 (15): E3013-21.

https://doi.org/10.1073/pnas.1620830114.

Narayan, Rumy, and Annika Tidström. 2019. "Circular Economy Inspired Imaginaries for Sustainable Innovations." In Innovation for Sustainability: Business Transformations Towards a Better World, edited by Nancy Bocken, Paavo Ritala, Laura Albareda, and Robert Verburg, 393-413. Palgrave Studies in Sustainable Business In Association with Future Earth. Cham: Springer International Publishing. https://doi.org/10.1007/978-3-319-97385-2_21.

National Academies of Sciences, Engineering and Medicine. 2018. Understanding the Long-Term Evolution of the Coupled Natural-Human Coastal System: The Future of the U.S. Gulf Coast. Washington, DC: National Academies Press. https://doi.org/10.17226/25108.

National Research Council. 1999. Our Common Journey: A Transition toward Sustainability. National Academy Press. http://www.nap.edu/catalog.php?record_id=9690.

National Research Council, Christopher D Mackie, Hermann Habermann, National Research Council (U.S.), and Panel on Measuring Social and Civic Engagement and Social Cohesion in Surveys. 2014. Civic Engagement and Social Cohesion: Measuring Dimensions of Social Capital to Inform Policy. Washington, DC: National Academies Press. https://doi.org/10.17226/18831.

Nelson, Donald R., W. Neil Adger, and Katrina Brown. 2007. "Adaptation to Environmental Change: Contributions of a Resilience Framework." Annual Review of Environment and Resources 32 (1): 395-419. https://doi.org/10.1146/annurev.energy.32.051807.090348. 
Nepal, Santosh, Nilhari Neupane, Devesh Belbase, Vishnu Prasad Pandey, and Aditi Mukherji. 2019. "Achieving Water Security in Nepal through Unravelling the Water-Energy-Agriculture Nexus." International Journal of Water Resources Development, December, 1-27.

https://doi.org/10.1080/07900627.2019.1694867.

Nestle, Marion. 2016. "Food Industry Funding of Nutrition Research: The Relevance of History for Current Debates." JAMA Internal Medicine 176 (11): 1685-86.

https://doi.org/10.1001/jamainternmed.2016.5400.

Nordhaus, William. 2019. "Economics of the Disintegration of the Greenland Ice Sheet." Proceedings of the National Academy of Sciences 116 (June): 201814990. https://doi.org/10.1073/pnas.1814990116.

Nordin, Martin, and Dan Olof Rooth. 2018. "The Intergenerational Transmission of Human Capital: The Role of Skills and Health." Journal of Population Economics 31 (4): 1035-65.

https://doi.org/10.1007/s00148-018-0702-3.

Oberlack, Christoph, Sébastien Boillat, Stefan Brönnimann, Jean-David Gerber, Andreas Heinimann, Chinwe Ifejika Speranza, Peter Messerli, Stephan Rist, and Urs Wiesmann. 2018. "Polycentric Governance in Telecoupled Resource Systems." Ecology and Society 23 (1): art16. https://doi.org/10.5751/ES-09902-230116.

Ocampo, Jose Antonio. 2016. Global Governance and Development. Oxford: Oxford University Press. https://doi.org/10.1093/acprof:oso/9780198785941.001.0001.

Ocasio-Cortez, Alexandria. 2019. Recognizing the Duty of the Federal Government to Create a Green New Deal. H. Res. 109. 116th Congress (2019-2020), 1st session.

OECD. 2018. "Global Material Resources Outlook to 2060 - Economic Drivers and Environmental Consequences - En - OECD.” 2018. http://www.oecd.org/environment/global-material-resourcesoutlook-to-2060-9789264307452-en.htm.

Oliver, Kathryn, Anita Kothari, and Nicholas Mays. 2019. "The Dark Side of Coproduction: Do the Costs Outweigh the Benefits for Health Research?" Health Research Policy and Systems 17 (1): 33.

https://doi.org/10.1186/s12961-019-0432-3.

O'Reilly, Charles A., and Michael Tushman. 2016. Lead and Disrupt: How to Solve the Innovator's Dilemma. Stanford, CA: Stanford Business Books, an imprint of Stanford University Press.

Österblom, Henrik, Jean-Baptiste Jouffray, Carl Folke, and Johan Rockström. 2017. "Emergence of a Global Science-Business Initiative for Ocean Stewardship." Proceedings of the National Academy of Sciences 114 (34): 9038-43. https://doi.org/10.1073/pnas.1704453114. 
Ostrom, Elinor. 2005. Understanding Institutional Diversity. Princeton Paperbacks. Princeton: Princeton University Press.

_- 2011. "Background on the Institutional Analysis and Development Framework." Policy Studies Journal 39 (1): 7-27. https://doi.org/10.1111/j.1541-0072.2010.00394.x.

Ostrom, Elinor, Marco A. Janssen, and John M. Anderies. 2007. "Going beyond Panaceas." Proceedings of the National Academy of Sciences 104 (39): 15176-78. https://doi.org/10.1073/pnas.0701886104.

Otto, Ilona M., Jonathan F. Donges, Roger Cremades, Avit Bhowmik, Richard J. Hewitt, Wolfgang Lucht, Johan Rockström, et al. 2020. “Social Tipping Dynamics for Stabilizing Earth's Climate by 2050.”

Proceedings of the National Academy of Sciences, 117 (January) :2354-65.

https://doi.org/10.1073/pnas.1900577117.

Palutikof, Jean P., Roger B. Street, and Edward P. Gardiner. 2019. "Looking to the Future: Guidelines for Decision Support as Adaptation Practice Matures." Climatic Change 153 (March): 643-655.

https://doi.org/10.1007/s10584-019-02404-x.

Pascual, Unai, Patricia Balvanera, Sandra Díaz, György Pataki, Eva Roth, Marie Stenseke, Robert T Watson, et al. 2017. "Valuing Nature's Contributions to People: The IPBES Approach." Current Opinion in Environmental Sustainability, Open issue, part II, 26-27 (June): 7-16.

https://doi.org/10.1016/j.cosust.2016.12.006.

Pattberg, Philipp, and Oscar Widerberg. 2016. “Transnational Multistakeholder Partnerships for Sustainable Development: Conditions for Success." Ambio 45 (1): 42-51. https://doi.org/10.1007/s13280015-0684-2.

Pearce, Catherine. 2019. "Guardians for Future Generations: Bringing Intergenerational Justice into the Heart of Policy-Making." In Intergenerational Equity: Environmental and Cultural Concerns, edited by $\mathrm{T}$ Cottier, S Lalani, C Siziba, 52-63. Leiden, Neth.: Brill.

Peattie, Ken. 2010. "Green Consumption: Behavior and Norms." Annual Review of Environment and Resources 35 (1): 195-228. https://doi.org/10.1146/annurev-environ-032609-094328.

Pedde, Simona, Kasper Kok, Katharina Hölscher, Niki Frantzeskaki, Ian Holman, Rob Dunford, Alison Smith, and Jill Jäger. 2019. "Advancing the Use of Scenarios to Understand Society's Capacity to Achieve the 1.5 Degree Target." Global Environmental Change 56 (May): 75-85.

https://doi.org/10.1016/j.gloenvcha.2019.03.010.

Pereira, Laura, Niki Frantzeskaki, Aniek Hebinck, Lakshmi Charli-Joseph, Scott Drimie, Michelle Dyer, Hallie Eakin, et al. 2020. “Transformative Spaces in the Making: Key Lessons from Nine Cases in the 
Global South." Sustainability Science 15 (1): 161-78. https://doi.org/10.1007/s11625-019-00749-x.

Pereira, Laura, Nadia Sitas, Federica Ravera, Amanda Jimenez-Aceituno, and Andrew Merrie. 2019.

"Building Capacities for Transformative Change towards Sustainability: Imagination in

Intergovernmental Science-Policy Scenario Processes." Elem Sci Anth 7 (1): 35.

https://doi.org/10.1525/elementa.374.

Perry, Andre, Jonathan Rothwell, and David Harshbarger. 2018. "The Devaluation of Assets in Black Neighborhoods: The Case of Residential Property." Brookings Metropolitan Policy Program.

https://www.brookings.edu/wp-content/uploads/2018/11/2018.11_Brookings-Metro_Devaluation-

Assets-Black-Neighborhoods_final.pdf.

Pershing, Andrew J., Nicholas R. Record, Bradley S. Franklin, Brian T. Kennedy, Loren McClenachan, Katherine E. Mills, James D. Scott, Andrew C. Thomas, and Nicholas H. Wolff. 2019. "Challenges to Natural and Human Communities from Surprising Ocean Temperatures." Proceedings of the National Academy of Sciences 116 (37): 18378-83. https://doi.org/10.1073/pnas.1901084116.

Peterson, Garry, Zuzana Harmáčková, Megan Meacham, Cibele Queiroz, Amanda Jiménez-Aceituno, Jan Kuiper, Katja Malmborg, Nadia Sitas, and Elena Bennett. 2018. "Welcoming Different Perspectives in IPBES: 'Nature's Contributions to People' and 'Ecosystem Services.”' Ecology and Society 23 (1): art39. https://doi.org/10.5751/ES-10134-230139.

Pierson, Paul, and Michèle Lamont, eds. 2019. “Inequality as a Multidimensional Process." Special Issue of Daedalus: Journal of the American Academy of Arts and Science 148 (3): 5-190.

Piketty, Thomas. 2020. Capital and Ideology. Translated by Arthur Goldhammer. Cambridge, MA: Harvard University Press.

Polasky, Stephen, Benjamin Bryant, Peter Hawthorne, Justin Johnson, Bonnie Keeler, and Derric Pennington. 2015. “Inclusive Wealth as a Metric of Sustainable Development." Annual Review of Environment and Resources 40 (1): 445-66. https://doi.org/10.1146/annurev-environ-101813-013253.

Polasky, Stephen, Stephen R. Carpenter, Carl Folke, and Bonnie Keeler. 2011. "Decision-Making under Great Uncertainty: Environmental Management in an Era of Global Change.” Trends in Ecology \& Evolution 26 (8): 398-404. https://doi.org/10.1016/j.tree.2011.04.007.

Preiser, Rika, Reinette Biggs, Alta De Vos, and Carl Folke. 2018. "Social-Ecological Systems as Complex Adaptive Systems: Organizing Principles for Advancing Research Methods and Approaches." Ecology and Society 23 (4): 46. https://doi.org/10.5751/ES-10558-230446. 
Quintana, Anastasia, and Lisa M. Campbell. 2019. "Critical Commons Scholarship: A Typology." International Journal of the Commons 13 (2): 1112-1127. https://doi.org/10.5334/ijc.925.

Raskin, Paul. 2016. Journey to Earthland: The Great Transition to Planetary Civilization. 1. Aufl. Boston, MA: Tellus Institute. https://greattransition.org/publication/journey-to-earthland.

Read, Rupert, and Tim O’Riordan. 2017. “The Precautionary Principle Under Fire." Environment: Science and Policy for Sustainable Development 59 (5): 4-15.

https://doi.org/10.1080/00139157.2017.1350005.

Renard, Delphine, and David Tilman. 2019. "National Food Production Stabilized by Crop Diversity." Nature 571 (June): 257-60. https://doi.org/10.1038/s41586-019-1316-y.

Reyers, Belinda, Carl Folke, Michele-Lee Moore, Reinette Biggs, and Victor Galaz. 2018. "SocialEcological Systems Insights for Navigating the Dynamics of the Anthropocene." Annual Review of Environment and Resources 43 (1): 267-89. https://doi.org/10.1146/annurev-environ-110615-085349.

Ribas, Aline, André F. P. Lucena, and Roberto Schaeffer. 2017. "Bridging the Energy Divide and Securing Higher Collective Well-Being in a Climate-Constrained World." Energy Policy 108: 435-50. https://doi.org/10.1016/j.enpol.2017.06.017.

Rocha, Juan C., Garry Peterson, Örjan Bodin, and Simon Levin. 2018. "Cascading Regime Shifts within and across Scales." Science 362 (6421): 1379-83. https://doi.org/10.1126/science.aat7850.

Rogge, Karoline S., Florian Kern, and Michael Howlett. 2017. "Conceptual and Empirical Advances in Analysing Policy Mixes for Energy Transitions." Energy Research \& Social Science, Policy mixes for energy transitions, 33 (November): 1-10. https://doi.org/10.1016/j.erss.2017.09.025.

Romsdahl, Rebecca, Gwendolyn Blue, and Andrei Kirilenko. 2018. "Action on Climate Change Requires Deliberative Framing at Local Governance Level." Climatic Change 149 (3-4): 277-87. https://doi.org/10.1007/s10584-018-2240-0.

Roser, Max. 2019. Our World in Data. 2019. https://ourworldindata.org/.

Rudel, Thomas K., and Monica Hernandez. 2017. "Land Tenure Transitions in the Global South: Trends, Drivers, and Policy Implications." Annual Review of Environment and Resources 42 (1): 489-507. https://doi.org/10.1146/annurev-environ-102016-060924.

Rudel, Thomas K., Patrick Meyfroidt, Robin Chazdon, Frans Bongers, Sean Sloan, H. Ricardo Grau, Tracy Van Holt, and Laura Schneider. 2020. "Whither the Forest Transition? Climate Change, Policy 
Responses, and Redistributed Forests in the Twenty-First Century." Ambio 49 (1): 74-84. https://doi.org/10.1007/s13280-018-01143-0.

Ruggie, John Gerard. 2013. Just Business: Multinational Corporations and Human Rights. First edition. Amnesty International Global Ethics Series. New York: W.W. Norton.

- _ 2014. "Global Governance and 'New Governance Theory': Lessons from Business and Human Rights." Global Governance 20 (1): 5-17.

Sachs, Jeffrey D., Guido Schmidt-Traub, Mariana Mazzucato, Dirk Messner, Nebojsa Nakicenovic, and Johan Rockström. 2019. "Six Transformations to Achieve the Sustainable Development Goals." Nature Sustainability 2 (9): 805-14. https://doi.org/10.1038/s41893-019-0352-9.

Sagarin, Raphael D., and Mary Turnipseed. 2012. “The Public Trust Doctrine: Where Ecology Meets Natural Resources Management." Annual Review of Environment and Resources 37 (1): 473-96. https://doi.org/10.1146/annurev-environ-031411-165249.

Sayles, J. S., M. Mancilla Garcia, M. Hamilton, S. M. Alexander, J. A. Baggio, A. P. Fischer, K. Ingold, G. R. Meredith, and J. Pittman. 2019. "Social-Ecological Network Analysis for Sustainability Sciences: A Systematic Review and Innovative Research Agenda for the Future." Environmental Research Letters 14 (9): 093003. https://doi.org/10.1088/1748-9326/ab2619.

Schaffartzik, Anke, Andreas Mayer, Simone Gingrich, Nina Eisenmenger, Christian Loy, and Fridolin Krausmann. 2014. "The Global Metabolic Transition: Regional Patterns and Trends of Global Material Flows, 1950-2010." Global Environmental Change 26 (May): 87-97.

https://doi.org/10.1016/j.gloenvcha.2014.03.013.

Scheffer, Marten. 2009. Critical Transitions in Nature and Society. Princeton, NJ: Princeton University Press. http://hollis.harvard.edu/?itemid=\%7Clibrary/m/aleph\%7C012052676.

Scheffer, Marten, Bas van Bavel, Ingrid A. van de Leemput, and Egbert H. van Nes. 2017. "Inequality in Nature and Society." Proceedings of the National Academy of Sciences 114 (50): 13154-57. https://doi.org/10.1073/pnas.1706412114.

Scheffer, Marten, Stephen R. Carpenter, Vasilis Dakos, and Egbert H. van Nes. 2015. "Generic Indicators of Ecological Resilience: Inferring the Chance of a Critical Transition." Annual Review of Ecology, Evolution, and Systematics 46 (1): 145-67. https://doi.org/10.1146/annurev-ecolsys-112414-054242.

Scheidel, Walter. 2017. The Great Leveler: Violence and the History of Inequality from the Stone Age to the Twenty-First Century. Princeton Economic History of the Western World. Princeton, NJ: Princeton University Press. 
Scheve, Kenneth, and David Stasavage. 2017. "Wealth Inequality and Democracy." Annual Review of Political Science 20 (1): 451-68. https://doi.org/10.1146/annurev-polisci-061014-101840.

Schlüter, Maja, L. Haider, Steven Lade, Emilie Lindkvist, Romina Martin, Kirill Orach, Nanda Wijermans, and Carl Folke. 2019. "Capturing Emergent Phenomena in Social-Ecological Systems: An Analytical Framework." Ecology and Society 24 (3): art11. https://doi.org/10.5751/ES-11012-240311.

Schot, Johan, Alejandra Boni, Matias Ramirez, and Fred Steward. 2018. “TIPC Research Brief: Addressing the Sustainable Development Goals Through Transformative Innovation Policy." 2018-01. Brighton, UK: Transformative Innovation Policy Consortium.

Schot, Johan, and W. Edward Steinmueller. 2018. "Three Frames for Innovation Policy: R\&D, Systems of Innovation and Transformative Change." Research Policy 47 (9): 1554-67.

https://doi.org/10.1016/j.respol.2018.08.011.

Schröder, Patrick, Philip Vergragt, Halina Szejnwald Brown, Leonie Dendler, Neal Gorenflo, Kira Matus, Jaco Quist, Christoph D. D. Rupprecht, Arnold Tukker, and Ronald Wennersten. 2019.

"Advancing Sustainable Consumption and Production in Cities - a Transdisciplinary Research and Stakeholder Engagement Framework to Address Consumption-Based Emissions and Impacts." Journal of Cleaner Production 213 (March): 114-25. https://doi.org/10.1016/j.jclepro.2018.12.050.

Scoones, Ian. 2009. "Livelihoods Perspectives and Rural Development." The Journal of Peasant Studies 36 (1): 171-96. https://doi.org/10.1080/03066150902820503.

- _ 2016. "The Politics of Sustainability and Development." Annual Review of Environment and Resources 41 (1): 293-319. https://doi.org/10.1146/annurev-environ-110615-090039.

Scoones, Ian, Melissa Leach, and Peter Newell, eds. 2015. The Politics of Green Transformations. Pathways to Sustainability. London; New York: Routledge.

Scoones, Ian, Andrew Stirling, Dinesh Abrol, Joanes Atela, Lakshmi Charli-Joseph, Hallie Eakin, Adrian Ely, et al. 2020. "Transformations to Sustainability: Combining Structural, Systemic and Enabling Approaches." Current Opinion in Environmental Sustainability, 42 (February): 65-75. https://doi.org/10.1016/j.cosust.2019.12.004.

Scott, James C. 1998. Seeing Like a State: How Certain Schemes to Improve the Human Condition Have Failed. Yale Agrarian Studies. New Haven: Yale University Press.

SDSN Association. 2019. “Sustainable Development Solutions Network.” 2019. https://www.unsdsn.org/. 
Sen, Amartya. 2013. "The Ends and Means of Sustainability." Journal of Human Development and Capabilities 14 (1): 6-20. https://doi.org/10.1080/19452829.2012.747492.

Sengers, Frans, Anna J. Wieczorek, and Rob Raven. 2019. “Experimenting for Sustainability Transitions: A Systematic Literature Review." Technological Forecasting and Social Change 145 (August): 153-64. https://doi.org/10.1016/j.techfore.2016.08.031.

Seto, Karen C., Steven J. Davis, Ronald B. Mitchell, Eleanor C. Stokes, Gregory Unruh, and Diana ÜrgeVorsatz. 2016. "Carbon Lock-in: Types, Causes, and Policy Implications." Annual Review of Environment and Resources 41 (1): 425-52. https://doi.org/10.1146/annurev-environ-110615-085934.

Seto, Karen C., Jay S. Golden, Marina Alberti, and B. L. Turner. 2017. "Sustainability in an Urbanizing Planet." Proceedings of the National Academy of Sciences 114 (34): 8935-38.

https://doi.org/10.1073/pnas.1606037114.

Shah, Tushaar, Mark Giordano, and Aditi Mukherji. 2012. "Political Economy of the EnergyGroundwater Nexus in India: Exploring Issues and Assessing Policy Options." Hydrogeology Journal 20 (5): 995-1006. http://dx.doi.org.ezp-prod1.hul.harvard.edu/10.1007/s10040-011-0816-0.

Sheely, Ryan. 2015. "Mobilization, Participatory Planning Institutions, and Elite Capture: Evidence from a Field Experiment in Rural Kenya." World Development 67 (March): 251-66. https://doi.org/10.1016/j.worlddev.2014.10.024.

Siddiqi, Afreen, and Ross D Collins. 2017. "Sociotechnical Systems and Sustainability: Current and Future Perspectives for Inclusive Development." Current Opinion in Environmental Sustainability, Sustainability science, 24 (February): 7-13. https://doi.org/10.1016/j.cosust.2017.01.006.

Sikkink, Kathryn. 2020. The Hidden Face of Rights: Toward a Politics of Responsibilities. The Castle Lectures in Ethics, Politics, and Economics. New Haven: Yale University Press.

Silvestre, Bruno S., and Diana Mihaela TTîrcă. 2019. "Innovations for Sustainable Development: Moving toward a Sustainable Future." Journal of Cleaner Production 208 (January): 325-32. https://doi.org/10.1016/j.jclepro.2018.09.244.

Sitaraman, Ganesh, Morgan Ricks, and Christopher Serkin. 2020. "Regulation and the Geography of Inequality." SSRN Scholarly Paper ID 3527055. Rochester, NY: Social Science Research Network. https://doi.org/10.2139/ssrn.3527055.

Sitas, Nadia, Zuzana V. Harmáčková, Jonathan A. Anticamara, Almut Arneth, Ruchi Badola, Reinette Biggs, Ryan Blanchard, et al. 2019. "Exploring the Usefulness of Scenario Archetypes in Science-Policy 
Processes: Experience across IPBES Assessments." Ecology and Society 24 (3): art35. https://doi.org/10.5751/ES-11039-240335.

Slate Staff. 2019. “Cashing in on Climate Change.” Slate Magazine, September 19, 2019. https://slate.com/business/2019/09/climate-change-crisis-companies-rich-lucky-farmingfirefighting.html.

Social Learning Group, William C. Clark, Jill Jäger, Jose VanEijndhoven, and Nancy Dickson, eds. 2001. Learning to Manage Global Environmental Risks, Vol 2: A Functional Analysis of Social Responses to Climate Change, Ozone Depletion and Acid Rain. Cambridge, MA: MIT Press.

Sovacool, Benjamin K., and Marie-Claire Brisbois. 2019. "Elite Power in Low-Carbon Transitions: A Critical and Interdisciplinary Review." Energy Research \& Social Science 57 (November): 101242. https://doi.org/10.1016/j.erss.2019.101242.

Spangenberg, Joachim H. 2019. "Scenarios and Indicators for Sustainable Development: Towards a Critical Assessment of Achievements and Challenges." Sustainability 11 (4): 942.

https://doi.org/10.3390/su11040942.

Steffen, Will, Katherine Richardson, Johan Rockström, Hans Joachim Schellnhuber, Opha Pauline Dube, Sébastien Dutreuil, Timothy M. Lenton, and Jane Lubchenco. 2020. "The Emergence and Evolution of Earth System Science." Nature Reviews Earth \& Environment 1 (1): 54-63.

https://doi.org/10.1038/s43017-019-0005-6.

Steffen, Will, Johan Rockström, Katherine Richardson, Timothy M. Lenton, Carl Folke, Diana Liverman, Colin P. Summerhayes, et al. 2018. "Trajectories of the Earth System in the Anthropocene." Proceedings of the National Academy of Sciences 115 (August): 8252-59.

https://doi.org/10.1073/pnas.1810141115.

Stiglitz, Joseph E. 2012. The Price of Inequality. 1st ed. New York: W.W. Norton.

- _ 2019. "Addressing Climate Change through Price and Non-Price Interventions." European Economic Review 119 (October): 594-612. https://doi.org/10.1016/j.euroecorev.2019.05.007.

Stiglitz, Joseph E., Jean-Paul Fitoussi, and Martine Durand. 2019. Measuring What Counts: The Global Movement for Well-Being. New York: The New Press.

Stirling, Andy. 2009. "Participation, Precaution and Reflexive Governance for Sustainable Development." In Governing Sustainability, edited by W. Neil Adger and Andrew Jordan, 193-225. Cambridge: Cambridge University Press. https://doi.org/10.1017/CBO9780511807756.011. 
_ _ 2019. “How Deep Is Incumbency? A 'Configuring Fields' Approach to Redistributing and Reorienting Power in Socio-Material Change." Energy Research \& Social Science 58 (December): 101239. https://doi.org/10.1016/j.erss.2019.101239.

Stokes, Donald E. 1997. Pasteur's Quadrant: Basic Science and Technological Innovation. Washington, DC: Brookings Institution Press.

Stokes, Leah C. 2020. Short Circuiting Policy: Interest Groups and the Battle Over Clean Energy and Climate Policy in the American States. Studies in Postwar American Political Development. Oxford; New York: Oxford University Press.

Suškevičs, Monika, Thomas Hahn, Romina Rodela, Biljana Macura, and Claudia Pahl-Wostl. 2018. "Learning for Social-Ecological Change: A Qualitative Review of Outcomes across Empirical Literature in Natural Resource Management." Journal of Environmental Planning and Management 61 (7): 10851112. https://doi.org/10.1080/09640568.2017.1339594.

Tellman, Beth, Julia Bausch, Hallie Eakin, John Anderies, Marisa Mazari-Hiriart, David ManuelNavarrete, and Charles Redman. 2018. "Adaptive Pathways and Coupled Infrastructure: Seven Centuries of Adaptation to Water Risk and the Production of Vulnerability in Mexico City." Ecology and Society 23 (1): art1. https://doi.org/10.5751/ES-09712-230101.

Tessum, Christopher W., Joshua S. Apte, Andrew L. Goodkind, Nicholas Z. Muller, Kimberley A. Mullins, David A. Paolella, Stephen Polasky, et al. 2019. "Inequity in Consumption of Goods and Services Adds to Racial-Ethnic Disparities in Air Pollution Exposure." Proceedings of the National Academy of Sciences 116 (13): 6001-6. https://doi.org/10.1073/pnas.1818859116.

Tilman, David, Forest Isbell, and Jane M. Cowles. 2014. "Biodiversity and Ecosystem Functioning." Annual Review of Ecology, Evolution, and Systematics 45 (1): 471-93. https://doi.org/10.1146/annurevecolsys-120213-091917.

Torpey-Saboe, Nichole, Krister Andersson, Esther Mwangi, Lauren Persha, Carl Salk, and Glenn Wright. 2015. "Benefit Sharing among Local Resource Users: The Role of Property Rights." World Development 72 (August): 408-18. https://doi.org/10.1016/j.worlddev.2015.03.005.

Trigeorgis, Lenos, and Jeffrey J. Reuer. 2017. “Real Options Theory in Strategic Management." Strategic Management Journal 38 (1): 42-63. https://doi.org/10.1002/smj.2593.

Tu, Chengyi, Samir Suweis, and Paolo D'Odorico. 2019. "Impact of Globalization on the Resilience and Sustainability of Natural Resources." Nature Sustainability 2 (4): 283-89.

https://doi.org/10.1038/s41893-019-0260-z. 
Turner, B. L., Karen J. Esler, Peter Bridgewater, Joshua Tewksbury, Nadia Sitas, Brent Abrahams, F Stuart Chapin, et al. 2016. "Socio-Environmental Systems (SES) Research: What Have We Learned and How Can We Use This Information in Future Research Programs." Current Opinion in Environmental Sustainability, Sustainability science, 19 (April): 160-68. https://doi.org/10.1016/j.cosust.2016.04.001.

Turnhout, Esther, Willemijn Tuinstra, and Willem Halffman. 2019. Environmental Expertise: Connecting Science, Policy, and Society. Cambridge; New York: Cambridge University Press.

Tzvetkova, Sandra, and Cameron Hepburn. 2018. “The Missing Economic Measure: Wealth." Our World in Data. https://ourworldindata.org/the-missing-economic-measure-wealth.

Underdal, Arild, and Taoyuan Wei. 2015. "Distributive Fairness: A Mutual Recognition Approach." Environmental Science \& Policy 51 (August): 35-44. https://doi.org/10.1016/j.envsci.2015.03.009.

United Nations. 2015. “Transforming Our World: The 2030 Agenda for Sustainable Development.” A/RES/70/1. New York: United Nations.

https://sustainabledevelopment.un.org/post2015/transformingourworld/publication.

United Nations Environment Programme (UNEP). 2019. “Global Chemicals Outlook II: From Legacies to Innovative Solutions: Implementing the 2030 Agenda for Sustainable Development." Nairobi, Kenya: UNEP. http://www.unenvironment.org/explore-topics/chemicals-waste/what-we-do/policy-andgovernance/global-chemicals-outlook.

United Nations Development Programme (UNDP. 2019. “Human Development Report 2019: Beyond Income, beyond Averages, beyond Today: Inequalities in Human Development in the 21st Century." New York: UNDP.

Veltmeyer, Henry. 2020. "Latin America in the Vortex of Social Change: Development and Social Movement Dynamics." World Development 130 (June): 104916.

https://doi.org/10.1016/j.worlddev.2020.104916.

Venkataraman, Bina. 2019. The Optimist's Telescope: Thinking Ahead in a Reckless Age. New York: Riverhead Books.

Villamayor-Tomas, Sergio, and Gustavo García-López. 2018. “Social Movements as Key Actors in Governing the Commons: Evidence from Community-Based Resource Management Cases across the World." Global Environmental Change 53 (November): 114-26.

https://doi.org/10.1016/j.gloenvcha.2018.09.005.

Wang, Chao, Pezhman Ghadimi, Ming K. Lim, and Ming-Lang Tseng. 2019. "A Literature Review of Sustainable Consumption and Production: A Comparative Analysis in Developed and Developing 
Economies." Journal of Cleaner Production 206 (January): 741-54.

https://doi.org/10.1016/j.jclepro.2018.09.172.

Webber, Sophie. 2019. "Putting Climate Services in Contexts: Advancing Multi-Disciplinary Understandings: Introduction to the Special Issue." Climatic Change 157 (November): 1-8. https://doi.org/10.1007/s10584-019-02600-9.

Weichselgartner, Juergen, and Berit Arheimer. 2019. "Evolving Climate Services into Knowledge-Action Systems." Weather, Climate, and Society 11 (2): 385-99. https://doi.org/10.1175/WCAS-D-18-0087.1.

Weiss, Edith Brown. 1988. In Fairness to Future Generations: International Law, Common Patrimony, and Intergenerational Equity. Tokyo, Japan; Dobbs Ferry, NY: United Nations University; Transnational Publishers.

Weisz, Helga, Sangwon Suh, and T. E. Graedel. 2015. “Industrial Ecology: The Role of Manufactured Capital in Sustainability." Proceedings of the National Academy of Sciences 112 (20): 6260-64. https://doi.org/10.1073/pnas.1506532112.

West, Simon, Lorrae van Kerkhoff, and Hendrik Wagenaar. 2019. "Beyond 'Linking Knowledge and Action': Towards a Practice-Based Approach to Transdisciplinary Sustainability Interventions." Policy Studies 40 (5): 534-55. https://doi.org/10.1080/01442872.2019.1618810.

Westley, Frances, Katharine McGowan, and Ola Tjörnbo. 2017. The Evolution of Social Innovation: Building Resilience Through Transitions. Cheltenham, UK: Edward Elgar Publishing.

White, Damian. 2020. "Just Transitions/Design for Transitions: Preliminary Notes on a Design Politics for a Green New Deal." Capitalism Nature Socialism 31(2):20-39.

https://doi.org/10.1080/10455752.2019.1583762.

Wibeck, Victoria, Björn-Ola Linnér, Melisa Alves, Therese Asplund, Anna Bohman, Maxwell T. Boykoff, Pamela M. Feetham, et al. 2019. "Stories of Transformation: A Cross-Country Focus Group Study on Sustainable Development and Societal Change." Sustainability 11 (8): 2427.

https://doi.org/10.3390/su11082427.

Wiebe, Keith, Monika Zurek, Steven Lord, Natalia Brzezina, Gnel Gabrielyan, Jessica Libertini, Adam Loch, Resham Thapa-Parajuli, Joost Vervoort, and Henk Westhoek. 2018. "Scenario Development and Foresight Analysis: Exploring Options to Inform Choices." Annual Review of Environment and Resources 43 (1): 545-70. https://doi.org/10.1146/annurev-environ-102017-030109.

Wildavsky, Aaron. 1980. "Richer Is Safer." The Public Interest / New York, 60:23-39. 
Williams, T. G., S. D. Guikema, D. G. Brown, and A. Agrawal. 2020. "Resilience and Equity: Quantifying the Distributional Effects of Resilience-Enhancing Strategies in a Smallholder Agricultural System." Agricultural Systems 182 (June): 102832. https://doi.org/10.1016/j.agsy.2020.102832.

Wing, Scott, and Members of the Anthropocene Working Group. 2019. "Letters: 'The Anthropocene Epoch Is Not Hubris." The Atlantic, October 11, 2019.

https://www.theatlantic.com/letters/archive/2019/10/readers-defend-the-anthropoceneepoch/597571/.

Wise, R. M., I. Fazey, M. Stafford Smith, S. E. Park, H. C. Eakin, E. R. M. Archer Van Garderen, and B. Campbell. 2014. "Reconceptualising Adaptation to Climate Change as Part of Pathways of Change and Response." Global Environmental Change 28 (September): 325-36.

https://doi.org/10.1016/j.gloenvcha.2013.12.002.

Wittmayer, Julia M., Flor Avelino, Frank van Steenbergen, and Derk Loorbach. 2017. "Actor Roles in Transition: Insights from Sociological Perspectives." Environmental Innovation and Societal Transitions 24 (September): 45-56. https://doi.org/10.1016/j.eist.2016.10.003.

World Commission on Environment and Development. 1987. Our Common Future. [Rev.]. Oxford; New York: Oxford University Press. http://hollis.harvard.edu/?itemid=\%7Clibrary/m/aleph\%7C001468050.

Wyborn, Carina, Amber Datta, Jasper Montana, Melanie Ryan, Peat Leith, Brian Chaffin, Clark Miller, and Lorrae van Kerkhoff. 2019. "Co-Producing Sustainability: Reordering the Governance of Science, Policy, and Practice." Annual Review of Environment and Resources 44 (1): 319-46.

https://doi.org/10.1146/annurev-environ-101718-033103.

Yamaguchi, Rintaro, and Shunsuke Managi. 2019. "Backward- and Forward-Looking Shadow Prices in Inclusive Wealth Accounting: An Example of Renewable Energy Capital." Ecological Economics 156 (February): 337-49. https://doi.org/10.1016/j.ecolecon.2018.09.020.

Yoshida, Yuki, Hirotaka Matsuda, Kensuke Fukushi, Shinya Ikeda, Shunsuke Managi, and Kazuhiko Takeuchi. 2018. "Assessing Local-Scale Inclusive Wealth: A Case Study of Sado Island, Japan.” Sustainability Science 13 (5): 1399-1414. https://doi.org/10.1007/s11625-018-0540-y.

Young, Oran R. 2011. "Effectiveness of International Environmental Regimes: Existing Knowledge, Cutting-Edge Themes, and Research Strategies." Proceedings of the National Academy of Sciences 108 (50): 19853-60. https://doi.org/10.1073/pnas.1111690108.

__ 2017. Governing Complex Systems: Social Capital for the Anthropocene. Cambridge, MA: MIT Press. 
- - 2018. "Research Strategies to Assess the Effectiveness of International Environmental Regimes." Nature Sustainability 1 (9): 461-65. https://doi.org/10.1038/s41893-018-0132-y.

Zimmerman, Julie B., Paul T. Anastas, Hanno C. Erythropel, and Walter Leitner. 2020. “Designing for a Green Chemistry Future." Science 367 (6476): 397-400. https://doi.org/10.1126/science.aay3060.

Zucman, Gabriel. 2019. “Global Wealth Inequality.” Annual Review of Economics 11 (1): 109-38. https://doi.org/10.1146/annurev-economics-080218-025852. 